\title{
Study on Titanium Dioxide Nanofibers as New Solid Phase Extraction Adsorbent for Column Preconcentration and Separation of Trace Rare Earth Elements Prior to their Determination by ICP-MS
}

\author{
Shizhong Chen ${ }^{\mathrm{a}, *}$, Juntao Yan $^{\mathrm{b}}$, Jianfen $\mathrm{Li}^{\mathrm{b}}$, and Dengbo $\mathrm{Lu}^{\mathrm{a}}$ \\ a College of Food Science and Engineering, Wuhan Polytechnic University, Wuhan 430023, P.R. China \\ b College of Chemical and Environmental Engineering, Wuhan Polytechnic University, \\ Wuhan 430023, P.R. China
}

\section{INTRODUCTION}

Owing to their wide application in agriculture and industry, the environmental pollution of rare earth elements (REEs) has attracted considerable attention (1-5). Several investigations demonstrated that continuous exposure to REEs, even at a low concentration level, could cause adverse health effects. It was reported that long-term intake of low-dose REEs may lead to accumulation in the bone structure, changes in the bone tissue, and aberration of bone marrow cells, even bringing about the generation of genetic toxicity in bone marrow cells (6-8). REEs can invade the central nervous system because they are susceptible to the cerebral cortex and cause subclinical damage (9). Therefore, the determination of trace REEs in biological and environmental samples is important for evaluating their possible effect on ecology, the environment, and human health.

Up-to-the present, various analytical techniques have been used for the determination of trace/ultratrace REEs in environmental and biological samples, which includes neutron activation analysis, isotopic dilution mass spectrometry, inductively coupled plasma mass spectrometry (ICP-MS), and inductively coupled plasma atomic emission spectrometry (10-13). In spite of the great improvement in instrumental power of detection at pre-

*Corresponding author.

E-mail: chenshizbong62@163.com

Tel: +862783956442

\section{ABSTRACT}

Based on titanium dioxide nanofibers (TDNFs) as a new adsorbent for solid phase extraction (SPE), a method was developed for the determination of trace rare earth elements in biological and environmental samples by inductively coupled plasma mass spectrometry (ICPMS). The adsorption behaviors of the analytes on TDNFs were studied systematically. The effects of the experimental parameters, including $\mathrm{pH}$, sample solution flow rate and volume, eluent concentration and volume, and interfering ions on the recoveries of the analytes, were examined in detail. Under the optimum conditions, the detection limits of this method ranged from $0.12 \mathrm{pg} \mathrm{mL}^{-1}(\mathrm{Lu})$ to 0.61 pg $\mathrm{mL}^{-1}(\mathrm{La})$, and the relative standard deviations (RSDs) for the determination of REEs were less than $4.5 \%(n=9, c=1.0 \mathrm{ng}$ $\left.\mathrm{mL}^{-1}\right)$. The linear range of the calibration curve spanned four orders of magnitude. This method was validated using a certified reference material of tea leaves and successfully applied for the determination of trace light (La), medium (Eu), and heavy $(\mathrm{Lu})$ rare earth elements in natural water samples with recoveries of $94.0-105 \%$.

sent, the direct determination of trace elements in extremely low concentrations by these techniques is in many cases difficult (14). This is not only due to insufficient sensitivity of the methods, but also the matrix interferences $(15,16)$. Thus, an effective separation and preconcentration step is still frequently required prior to their determination.

Of preconcentration and separation procedures, solid-phase extraction (SPE) has received increasing attention because of (i) high concentration factor, (ii) simple operation, (iii) rapid phase separation, and (iv) the possibility of combining with different analytical techniques (17-19). It is worth noting that adsorbent materials play a critical role in the microcolumn SPE techniques to improve the analytical performance of a method. Various materials, such as activated carbon, bis(3-aminopropyl)aminebonded silica gel, alkyl phosphinic acid resin, brown seaweeds, fly ash, coconut shell powder, and 2,6diacetylpyridine functionalized amberlite XAD- 4 , have been developed for the preconcentration and separation of trace/ultra-trace elements (20-26).

In recent years, nanostructure materials as a new type of adsorbents for preconcentration and separation of trace/ultratrace substances have drawn growing attention owing to their small size, large specific surface area, excellent mechanical strength, high chemical stability, and unique electrical properties. Consequently, they can selectively adsorb metal ions, and have a very high adsorption capacity. Some nanometer-size substances, such as carbon nanotubes, carbon nanofibers, titanium dioxide nanotubes, $\mathrm{Fe}_{3} \mathrm{O}_{4}$ nanoparticles, chrysin-functionalized silica-core 
shell magnetic nanoparticles, $\mathrm{ZnO}$ nanoparticles, nanometer-sized zirconium oxide, $\mathrm{Fe}_{3} \mathrm{O}_{4} @ \mathrm{ZrO}_{2}$ nanoparticles, and modified ionic liquid-coated nanometer $\mathrm{TiO}_{2}$ have been successfully used for the preconcentration and separation of trace elements and their species (27-35). Titanium dioxide nanofibers (TDNFs), as an interesting member in the titanium nanomaterial family, possess some unique properties, such as large specific surface area, high chemical stability, corrosionresistance, non-toxicity, and low cost. All of the facts mentioned above indicate that TDNFs could have great analytical potential as an effective solid phase extraction adsorbent. To the best of our knowledge, however, there is no study available in the public domain.

The aim of this work was to investigate the feasibility of TDNFs as a new SPE adsorbent for the preconcentration and determination of trace REEs. On the basis of the experimental results obtained, a method using a microcolumn packed with TDNFs coupled with ICP-MS was developed for the determination of trace light (La), medium (Eu), and heavy (Lu) REEs in biological and environmental samples.

\section{EXPERIMENTAL}

\section{Instrumentation}

An Series-7 ICP-MS system (Thermo Fisher Scientific Corporation, USA) was used for the determination. The optimum operating conditions for ICP-MS are summarized in Table I.

The $\mathrm{pH}$ values of the solutions were measured with a $\mathrm{pH}$ meter (Thermo Orion Corporation, USA) supplied with a combined electrode. A HL-2 peristaltic pump (Shanghai Qingpu Huxi Instrument Factory, P.R. China), coupled with a self-made polytetrafluoroethylene
(PTFE) microcolumn $(20 \mathrm{~mm} \times 3.0$ mm i.d.) packed with TDNFs, was used for the preconcentration/separation process. A minimum length of PTFE tube with an inner diameter of $0.5 \mathrm{~mm}$ was used for all connections. A Model Ethos T microwave system (Milestone, Italy) was used for sample digestion.

\section{Standard Solution and Reagents}

Stock standard solutions $(1.0 \mathrm{mg}$ $\mathrm{mL}^{-1}$ ) of REEs and indium (In) were obtained from the National Analysis Center of Iron \& Steel (Beijing, P.R. China). Working solutions were prepared daily by appropriate dilution of the stock solutions. All reagents used were ultrapure or analytical grade. The $\mathrm{pH}$ values of the solution were achieved by adding an appropriate amount of $\mathrm{HNO}_{3}$ or ammonia water $\left(\mathrm{NH}_{3} \cdot \mathrm{H}_{2} \mathrm{O}\right)$. The TDNFs were synthesized and characterized in our laboratory. High purity deionized water (18.2 M $\Omega$ ) obtained from a Milli-Q ${ }^{\circledR}$ A10 system (Millipore Corporation, USA) was used throughout this work.

\section{Column Preparation}

A PTFE microcolumn (20 $\mathrm{mm} \times$ $3.0 \mathrm{~mm}$ i.d.) plugged with a small portion of glass wool at both ends was filled with 100 milligrams of TDNFs. Before use, $1.0 \mathrm{~mol} \mathrm{~L}^{-1}$

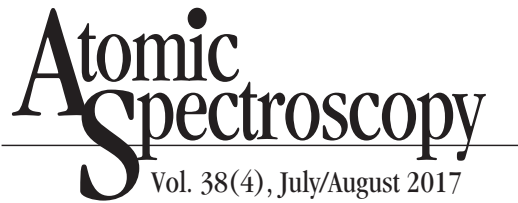

$\mathrm{HNO}_{3}$ solution and high purity deionized water were passed through the column in order to clean and condition it. Then, the column was conditioned to the desired $\mathrm{pH}$ value with $\mathrm{HNO}_{3}$ and $\mathrm{NH}_{3} \cdot \mathrm{H}_{2} \mathrm{O}$.

\section{Sample Decomposition}

A sample portion of $0.2000 \mathrm{~g}$ (tea leaves) was accurately weighed into a $100-\mathrm{mL}$ Teflon ${ }^{\circledR}$ vessel, and then $4.0 \mathrm{~mL}$ concentrated $\mathrm{HNO}_{3}$ and $2.0 \mathrm{~mL}$ of $\mathrm{H}_{2} \mathrm{O}_{2}(35 \%, \mathrm{~m} / \mathrm{v})$ were added, respectively. The solid particles attached to the wall of the Teflon vessels were rinsed with the digestion reagents. After about 5 minutes when the first vigorous reaction had taken place, the digestion vessels were closed and placed into a microwave oven. After that, the samples were digested in the microwave oven at $180{ }^{\circ} \mathrm{C}$ (ramp, 10 minutes; hold, 15 minutes) at a power of $1.0 \mathrm{~kW}$. After cooling, the solution was transferred into a Teflon beaker, $0.3 \mathrm{~mL} \mathrm{HClO}_{4}$ was added and heated to near dryness on a hot plate at $200^{\circ} \mathrm{C}$. The residues were dissolved with $0.1 \mathrm{~mol} \mathrm{~L}^{-1} \mathrm{HNO}_{3}$ solution, and diluted to a desired volume. A natural water sample, collected from Dongxi Lake of Wuhan, was filtered through a $0.22-\mu \mathrm{m}$ membrane filter and analyzed as soon as possible

TABLE I

Operating Parameters for ICP-MS

\begin{tabular}{ll}
\hline Plasma Power & $1300 \mathrm{~W}$ \\
Plasma Argon Flow Rate & $14.5 \mathrm{~L} \mathrm{~min}^{-1}$ \\
Auxiliary Argon Flow Rate & $0.81 \mathrm{~L} \mathrm{~min}^{-1}$ \\
Nebulizer Argon FlowRate & $0.93 \mathrm{~L} \mathrm{~min}{ }^{-1}$ \\
Sampler Orifice (Ni) & $1.1 \mathrm{~mm}$ \\
Skimmer Orifice (Ni) & $0.7 \mathrm{~mm}$ \\
Acquisition Mode & Peak Jumping \\
Number of Sweep & 100 \\
Dwell Time & $10 \mathrm{~ms}$ \\
Acquisition Time & $40 \mathrm{~s}$ \\
Number of Measurements per Peak & 3 \\
Isotopes & $139 \mathrm{La},{ }^{153} \mathrm{Eu},{ }^{175} \mathrm{Lu}$, and ${ }^{115} \mathrm{In}$ \\
\hline
\end{tabular}


after sampling. The blank was prepared exactly as the samples.

\section{General Procedure}

Sample solutions were prepared by appropriate dilution of the stock solutions and adjusted to the desired $\mathrm{pH}$ with $\mathrm{HNO}_{3}$ or $\mathrm{NH}_{3} \cdot \mathrm{H}_{2} \mathrm{O}$ before use. The obtained solution was passed through the column by using a peristaltic pump at the desired flow rate. Afterwards, the retained REE ions were eluted with $2.0 \mathrm{~mL}$ of $0.5 \mathrm{~mol} \mathrm{~L}^{-1} \mathrm{HNO}_{3}$ solution. The analytes in the effluents were determined by ICP-MS. The column could be used repeatedly after regeneration with $1.0 \mathrm{~mol} \mathrm{~L}^{-1}$ $\mathrm{HNO}_{3}$ and deionized water, respectively. The recoveries of the analytes were calculated from the ratio of the concentration found by ICPMS to that of the initial sample. The samples and standards were spiked with $2.0 \mathrm{ng} \mathrm{mL}^{-1}$ of indium internal standard prior to their analysis.

\section{RESULTS AND DISCUSSION}

\section{Characterization of TDNFs}

The TDNFs were fabricated by a facile electrospinning and subsequent annealing method. The surface morphology of TDNFs was characterized by scanning electron microscopy (SEM, SSX-550,
Shimadzu, Japan). From Figure 1, it can be seen that TDNFs have a onedimensional structure and exhibit a rough surface with many pores on it. The diameter of TDNFs is mainly in the range of $350-450 \mathrm{~nm}$ by Image $\mathrm{J}$ Software. In addition, $\mathrm{Ti}$ and $\mathrm{O}$ are only detected in the EDX spectrum, except for Au which comes from sample pretreatment, and suggests that pure TDNFs were obtained in this study. It is, therefore, clear that TDNFs with porous surfaces should have great analytical potential as an adsorbent.

\section{Effect of pH on Adsorption}

Retention of the REE ions on the column packed with TDNFs was studied as a function of $\mathrm{pH}$ values. For this purpose, the $\mathrm{pH}$ values of the solutions were adjusted between 1.0 and 8.0 with $\mathrm{HNO}_{3}$ or $\mathrm{NH}_{3} \cdot \mathrm{H}_{2} \mathrm{O}$. The adsorption percentage was calculated based on the difference between the amounts of REEs in the starting sample and the solution from the column. As shown in Figure 2, the adsorption of the studied ions on TDNFs was quantitative $(>90 \%)$ in part of the $\mathrm{pH}$ range 6.0-8.0. Therefore, a $\mathrm{pH}$ of 7.0 was used throughout this work.

\section{Optimization of Elution Conditions}

The eluent is an important parameter in SPE which can influence the enrichment performance because it determines whether or not the analytes are eluted completely from the adsorbent. From Figure 2, it can be seen that the adsorption of REEs on TDNFs could be negligible at $\mathrm{pH}<1.0$. For this reason, various concentrations of $\mathrm{HNO}_{3}$ solution were studied for desorption of the retained REEs from the microcolumn. The experimental results in Table II indicate that $1.0 \mathrm{~mol} \mathrm{~L}^{-1} \mathrm{HNO}_{3}$ was sufficient for complete elution. In addition, the effect of eluent volume on the recovery of the analytes was investigated by keeping the $\mathrm{HNO}_{3}$ concentration of $1.0 \mathrm{~mol} \mathrm{~L}^{-1}$. It was found

TABLE II

Effect of Eluent Concentration on the Recoveries of Analytes

\begin{tabular}{cccc}
\hline $\begin{array}{c}\text { Eluent } \\
\left(\mathrm{HNO}_{3}^{\mathrm{a}},\right. \\
\left.\mathrm{mol} \mathrm{L}^{-1}\right)\end{array}$ & $\mathrm{La}^{3+}$ & $\mathrm{Eu}^{3+}$ & $\mathrm{Lu}^{3+}$ \\
\hline 0.2 & 50.2 & 64.3 & 56.9 \\
0.4 & 68.7 & 78.2 & 73.8 \\
0.8 & 84.9 & 89.7 & 83.9 \\
1.0 & 95.7 & 97.2 & 98.1 \\
1.2 & 98.2 & 101 & 99.2 \\
1.5 & 102 & 98.2 & 96.7 \\
\hline
\end{tabular}

${ }^{a}$ Eluent volume: $2.0 \mathrm{~mL}$

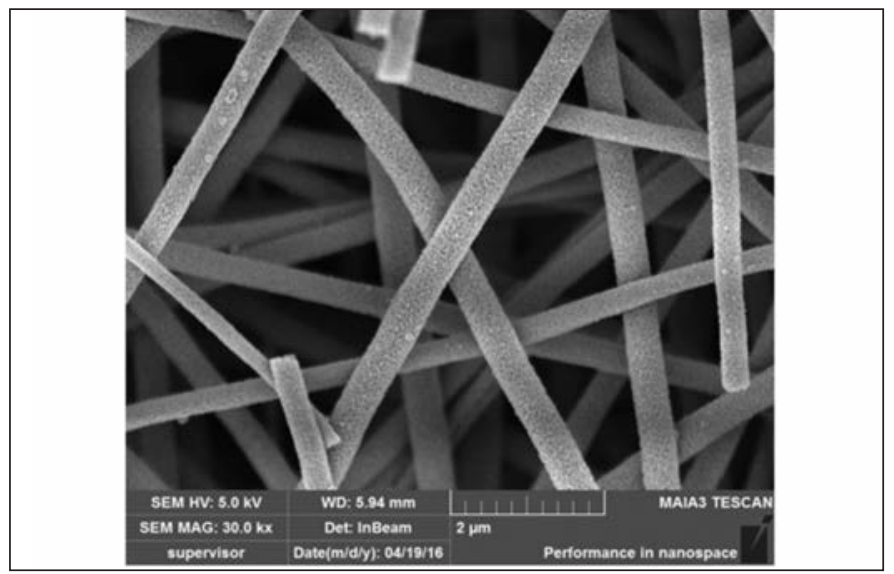

Fig. 1. SEM images of TDNFs.

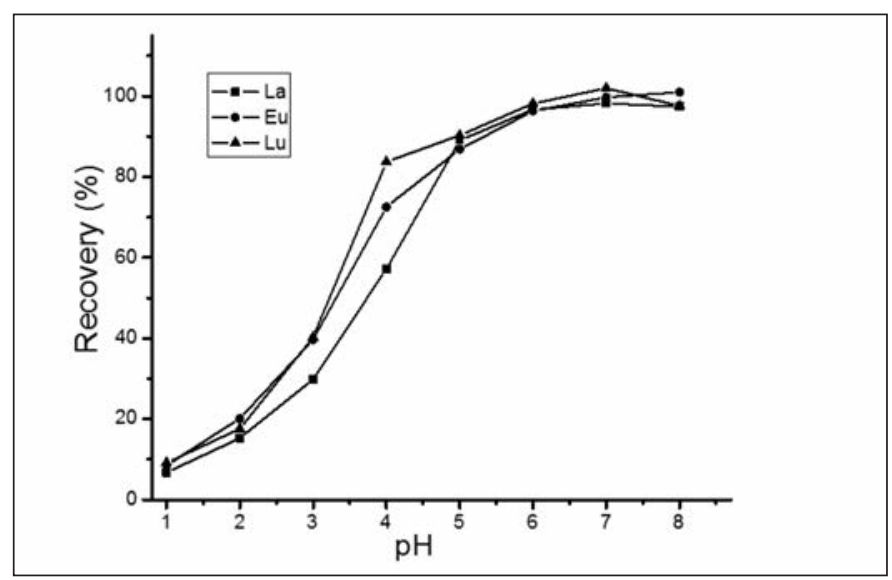

Fig. 2. Effect of $p H$ on the recovery of REEs on TDNFs. REEs $^{3+}$ : $1.0 \mathrm{ng} \mathrm{mL}^{-1}$; sample volume: $20 \mathrm{~mL}$. 


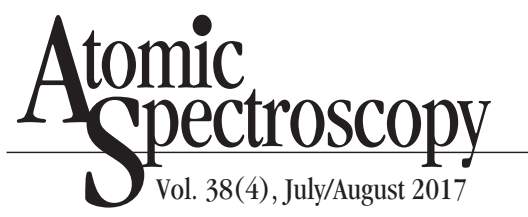

that quantitative recoveries ( $>90 \%$ ) could be obtained with $2.0 \mathrm{~mL}$ of $1.0 \mathrm{~mol} \mathrm{~L}^{-1} \mathrm{HNO}_{3}$. Hence, $2.0 \mathrm{~mL}$ of $\mathrm{HNO}_{3}$ was adopted in this work.

\section{Effect of Sample Solution Flow Rate}

The effect of sample flow rate on adsorption percentage of the analytes was investigated under optimum conditions. The solution was passed through the microcolumn with a flow rate in the range of $0.2-3.0 \mathrm{~mL} / \mathrm{min}$. As can be seen in Figure 3, at the flow rate greater than $1.5 \mathrm{~mL} \mathrm{~min}^{-1}$, there was a decrease in the recoveries of the studied ions. The reason for this is probably due to insufficient contact of the metal ions and the adsorbent to reach equilibrium. Therefore, a flow rate of $1.0 \mathrm{~mL} \mathrm{~min}{ }^{-1}$ was used for the determination of the analytes in the subsequent experiment.

\section{Influence of Sample Solution Volume}

Biological and environmental samples usually contain REE ions at a very low concentration level. In order to determine the maximum volume (or minimum analyte concentration), the effect of changes in the volume of the sample solution passing through the microcolumn on the retention of the analytes was also examined (Figure 4). Amounts of 20,50,100,150,200, 250, and $300 \mathrm{~mL}$ of the sample solution containing $5.0 \mathrm{ng}$ REEs ions were passed through the microcolumn under the optimum conditions. It was found that all analytes could be recovered quantitatively (>90\%) up to $250 \mathrm{~mL}$ of the sample solution. In this study, because the elution volume was $2.0 \mathrm{~mL}$, an enrichment factor of 125 could be obtained for the studied ions. Considering the analyte time, a 20-mL sample volume was used for the analysis of the real samples.

\section{Effect of Interfering Ions}

In general, coexisting ions will influence the determination of target ions by competing for the active sites of the adsorbents. Thus, the effects of common coexisting ions on the adsorption of REEs on TDNFs were investigated. In these experiments, various salts and ions were added individually to a solution containing $1.0 \mathrm{ng} \mathrm{mL}^{-1}$ REEs according to the recommended procedure under the optimum conditions. The tolerance limit of coexisting ions is defined as the largest amount making the recovery of the analyte less than $90 \%$. The results obtained are given in Table III. It can be seen that the presence of major cations and anions has no obvious influence on the adsorption of the analytes.

\section{Column Reuse}

In order to examine the longterm stability of TDNFs, they were subjected to successive adsorption and desorption cycles by passing $20 \mathrm{~mL}$ of REE solutions through the microcolumn. The potential regeneration of the column packed with TDNFs was studied by monitoring the changes in the recoveries of the REEs in this work. The column can be reused after regeneration with $20 \mathrm{~mL}$ of $1.0 \mathrm{~mol} \mathrm{~L}^{-1} \mathrm{HNO}_{3}$ and $20 \mathrm{~mL}$ deionized water, respectively, and is stable up to 50 adsorptionelution cycles with recoveries of the analytes in the range of $95.6 \%-103 \%$.

TABLE III Tolerance Limits of Coexisting Ions

\begin{tabular}{lr}
\hline Coexisting Ion & Mass Ratio \\
\hline $\mathrm{Na}^{+}, \mathrm{K}^{+}$ & $20,000^{\mathrm{b}}$ \\
$\mathrm{Ca}^{2+}, \mathrm{Mg}^{2+}$ & $10,000^{\mathrm{b}}$ \\
$\mathrm{Fe}^{3+}, \mathrm{Zn}^{2+}, \mathrm{Al}^{3+}$ & $400^{\mathrm{b}}$ \\
$\mathrm{SO}_{4}^{2-}, \mathrm{SiO}_{3}{ }^{2-}, \mathrm{PO}_{4}{ }^{3-}$ & $3000^{\mathrm{b}}$ \\
$\mathrm{Cl}^{-1}, \mathrm{NO}_{3}{ }^{-1}$ & $20,000^{\mathrm{b}}$ \\
\hline
\end{tabular}

a Mass ratio: Foreign ion / $\mathrm{REE}^{3+}$.

${ }^{\mathrm{b}}$ Maximum amounts tested.

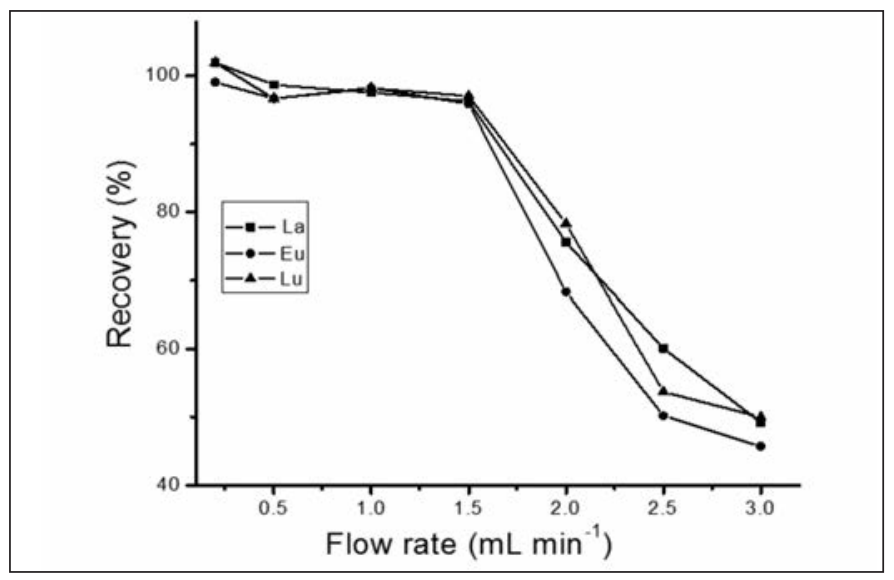

Fig. 3. Effect of flow rate on the recovery of REEs on TDNFs. REEs $^{3+}: 1.0 \mathrm{ng} \mathrm{mL}^{-1}$; sample volume : $20 \mathrm{~mL}$.

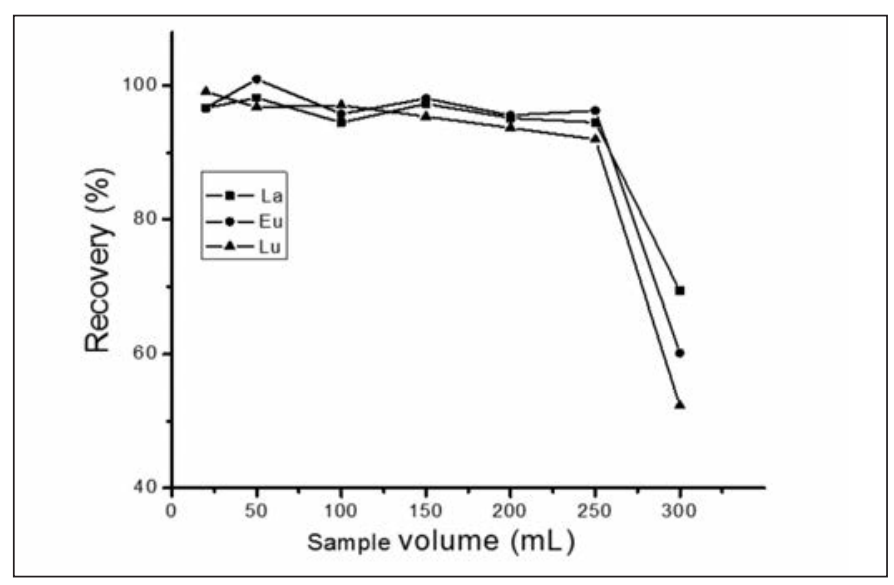

Fig. 4. Effect of sample volume on the recovery of analytes on TDNFs. REEs : $5.0 \mathrm{ng} ; \mathrm{pH}: 7.0$. 


\section{Analytical Performance}

According to the definition of IUPAC, the detection limit is defined as the concentration corresponding to three times the standard deviation of the blanks. Under the optimum conditions, the detection limits (DLs) and relative standard deviations (RSDs) of the analytes for this method are summarized in Table IV $(n=9, c=1.0$ $\mathrm{ng} \mathrm{mL}^{-1}$ ). The linear range of this method was from 0.1 to $100 \mathrm{ng} \mathrm{mL}^{-1}$ with the correlation coefficient better than 0.9993 .

TABLE IV

Detection Limits and Relative Standard Deviations $(\mathbf{n}=9)$

\begin{tabular}{cccc}
\hline Element & Isotopes & $\begin{array}{c}\text { DLs } \\
\left(\mathrm{pg} \mathrm{mL}^{-1}\right)\end{array}$ & $\begin{array}{c}\text { RSDs } \\
(\%)\end{array}$ \\
\hline $\mathrm{La}$ & 139 & 0.61 & 3.5 \\
$\mathrm{Eu}$ & 153 & 0.25 & 2.1 \\
$\mathrm{Lu}$ & 175 & 0.12 & 4.4 \\
\hline
\end{tabular}

\section{Analysis Application}

To establish the validity of this method, a certified reference material GBW 07605 Tea Leaves was analyzed by this procedure. The results are summarized in Table $\mathrm{V}$. The determined values are in good agreement with the certified values for the analytes. The proposed method was also applied to the determination of analytes in a natural water sample. Various amounts of analytes were also spiked to the water sample. The results are given in Table VI. Good agreement was obtained between the added and measured analyte amounts. The recoveries of the analytes were in the range of $94.0 \%-105 \%$.

\section{CONCLUSION}

Titanium dioxide nanofibers (TDNFs) were used as a new solid phase extractor for the preconcentration, separation, and determination of trace/ultra-trace rare earth elements (REEs) in biological and environmental samples by ICP-MS.
TABLE V

\section{Analytical Results of Analytes in Certified Reference Material} of Tea Leaves

\begin{tabular}{ccc}
\hline $\begin{array}{c}\text { Ele- } \\
\text { ment }\end{array}$ & $\begin{array}{c}\text { Found }^{\mathrm{a}} \\
\left(\mu \mathrm{g} \mathrm{g}^{-1}\right)\end{array}$ & $\begin{array}{c}\text { Certified } \\
\left(\mu \mathrm{g} \mathrm{g}^{-1}\right)\end{array}$ \\
\hline $\mathrm{La}$ & $0.56 \pm 0.04$ & $0.60 \pm 0.03$ \\
$\mathrm{Eu}$ & $0.022 \pm 0.002$ & $0.018 \pm 0.002$ \\
$\mathrm{Lu}$ & $0.006 \pm 0.0008$ & $0.007^{\mathrm{b}}$
\end{tabular}

${ }^{\mathrm{a}}$ Mean value \pm standard deviation, $\mathrm{n}=3$.

${ }^{\mathrm{b}}$ Reference values.

\section{TABLE VI}

Analytical Results and Recoveries of Analytes in Natural Water Sample

\begin{tabular}{cccc}
\hline $\begin{array}{c}\text { Ele- } \\
\text { ment }\end{array}$ & $\begin{array}{c}\text { Added } \\
\text { ng mL }\end{array}$ & $\begin{array}{c}\left.\text { Found }^{-1}\right) \\
\left(\mathrm{ng} \mathrm{mL}^{-1}\right)\end{array}$ & $\begin{array}{c}\text { Recovery } \\
(\%)\end{array}$ \\
\hline La & - & $3.21 \pm 0.14$ & - \\
& 2.0 & $5.15 \pm 0.32$ & 97.0 \\
& 5.0 & $8.03 \pm 0.52$ & 96.4 \\
Eu & - & $1.31 \pm 0.07$ & - \\
& 2.0 & $3.37 \pm 0.15$ & 103 \\
& 5.0 & $6.22 \pm 0.37$ & 98.2 \\
Lu & - & $0.18 \pm 0.02$ & \\
& 0.2 & $0.39 \pm 0.04$ & 105 \\
& 0.5 & $0.65 \pm 0.05$ & 94.0 \\
\hline
\end{tabular}

${ }^{a}$ Mean value \pm standard deviation, $\mathrm{n}=3$.

The adsorption behavior of the REEs on TDNFs was investigated systematically. The analytes can be retained on TDNFs in the $\mathrm{pH}$ range of 6.0-8.0, desorbed quantitatively with $2 \mathrm{~mL}$ of $1.0 \mathrm{~mol} \mathrm{~L}^{-1} \mathrm{HNO}_{3}$, and no carryover is observed in the next analysis. An enrichment factor of 125 was achieved. In addition, the obtained experimental results demonstrated that TDNFs are likely to become a significant potential solid phase extraction sorbent for the separation, preconcentration, and determination of trace/ultratrace elements in various real-world samples.

\section{ACKNOWLEDGMENT}

The authors are grateful for the financial support of Special Fund for Agroscientific Research in the Public Interest (Project No. 201503135-22).

Received February 5, 2017.

\section{REFERENCES}

1. S. Zhang and X. Shan, Environ. Poll. 112, 395 (2001).

2. M.C. Saha, S. Lahiri, R. Baskey, and F. Kharshiing, At. Spectrosc. 37(5), 171 (2016).

3. E.K. Atibu, N. Devarajan, A. Laffite, G. Giuliani, J.A. Salumu, R.C. Muteb, C.K. Mulaji, J.P. Otamonga, V. Elongo, and P.T. Mpiana, Chem. Erde-Geochem. 76(3), 353 (2016).

4. F.G. Pinto, J. Tronto, F.G. Lepri, L. Tormen, T.D. Saint'Pierre, L.M. Costa, M.A. Beinner, and J.B.B. da Silva, At. Spectrosc. 36(3), 116 (2015).

5. A.V. Gobnov, M.V. Frontasyeva, S.F. Gundorina, T.L. Onichenko, B.B. Maksjuta, and C.S. Pal, Sci. Total. Environ. 122, 337 (1992).

6. R.A. Lagad, D. Alamelu, A.K. Chaudhary, and S.K. Aggarwal, At. Spectrosc. 33(4), 109 (2012).

7. S. Hirano and K.T. Suzuki, Environ. Health Perspect. 104, 85 (1996).

8. Z. Chen and X. Zhu, J. Ecol. Rural Environ. 24, 88 (2008).

9. W. Zhu, S. Xu, P. Shao, H. Zhang, D. Wu, W. Yang, and J. Feng, Biol. Trace Elem. Res. 57, 71 (1997).

10. M. Krishnakumar, K. Satyanarayana, and K. Mukkanti, At. Spectrosc. 36(2), 74 (2015).

11. S. Spalla, C. Baffi, C. Barbante, C. Turretta, G. Cozzi, G.M. Beone, and M. Bettinelli, Rapid Commun. Mass Spectrom. 23, 3285 (2009).

12. M.C. Saha, R.S. Alte, and N.K. Roy, At. Spectrosc. 36(3), 109 (2015).

13. T.J. Shaw, T. Duncan, and B.A Schnetger, Anal. Chem. 75, 3396 (2003). 
14. J. S. Jones, B. A.Harrington, W. R. Leone, and W. R. Brandstedt, At. Spectrosc. 4, 49 (1983).

15. M. Angel, A.M.E. Hayat, and P. Rose, Anal. Chem. 66, 3632 (1994).

16. E. Vassileva, I. Proinova, and K. Hadjiivanov, Analyst 121, 607 (1996).

17. V. A. Lemos, L.S.G. Teixeira, M.A. Bezerra, A.C.S. Costa, J.T. Castro, L.A.M. Cardoso, D.S. de Jesus, E.S. Santos, P.X. Baliza, and L.N. Santos, Appl. Spectrosc. Rev. 43, 303 (2008).

18. V. Camel, Spectrochim. Acta Part B 58, 1177 (2003).

19. S. Chen, J. Li, Y. He, and D. Lu, At. Spectrosc. 37(3), 96 (2016).

20. P.L. Mahanta, G. Chakrapani, and R. Radhamani, At. Spectrosc. 31(1), 21 (2010).

21. M.M. Figueira, B. Volesky, V.S.T. Ciminelli, and F.A. Roddick, Water Res. 34, 196 (2000).

22. Q. Fu, L. Yang, and Q. Wang, Talanta 72, 1248 (2007).

23. A. Elif, I. Mustafa, and A. Huseyin, At. Spectrosc. 34(4), 146 (2013).

24. E. Pehlivan, S. Cetin, and B.H. Yanik, J. Hazard. Mater. 135, 193 (2006).

25. G.H. Pino, L.M.S. De Mesquita, M.L. Torem, and G.A.S. Pinto, Miner. Eng. 19, 380 (2006).

26. C. Karadaş, D. Kara, and A. Fisher, Anal. Chim. Acta 689, 184 (2011).

27. S. Tong, S. Zhao, W. Zhou, R. Li, and Q. Jia, Microchim. Acta 174(34), 257 (2011).

28. S. Chen, S. Zhu, Y. He, and D. Lu, Food Chem. 150, 254 (2014).

29. Y. He, S. Chen, X. Zhou, and X. Wang, At. Spectrosc. 33(4), 117 (2012).

30. L.I.A. Ali, W.A.W. Ibrahim, A. Sulaiman, M.A. Kamboh, and M.M. Sanag, Talanta 148, 191 (2016).

31. F. Zheng, S. Li, L. Lin, and L. Cheng, J. Hazard. Mater. 172(2-3), 618 (2009).

32. S. Ewa and K. Magdalena, Microchem. J. 32, 136 ( 2017).

33. W. Tian and Z. Fan, Spectrosc.
33(1), 36 (2012).

34. Y. Wu, J. Zhang, J. Liu, L. Chen, Z. Deng, M. Han, X. Wei, A. Yu, and H. Zhan, Appl. Surf. Sci. 258(18), 6772 (2012).

35. M. Amjadi and A. Samadi, Coll. Surf. A 434, 171 (2013). 